\title{
Substitution of wheat flour by local cereals and pulses flour "An approach to overcome wheat gap in Egypt" 1. Protein and dry gluten content of flour
}

\author{
Zeinab R.Atia ${ }^{1}$, M.M El-Genbeihy ${ }^{2}$ and M.Abd El- Sattar Ahmed ${ }^{2 *}$ \\ ${ }^{1}$ Postgraduate student, Crop Science Dept., Fac.Agric. (El-Shatby), Alexandria university. \\ (zeinabraafat@yahoo.com) \\ ${ }^{2}$ Crop Science Dept., Fac.Agric. (El-Shatby), Alexandria university. \\ * (sattaralexun@yahoo.com)
}

\begin{abstract}
In Egypt, bread is traditionally produced from wheat "'Triticum aestivum" flour. Due to high demand, about 50\%of needed wheat is imported. The inability to sustain the national wheat imports for making wheat based foods, makes is imperative that some substitutes for wheat must be incorporated in the bread preparation. Alternative non wheat cereals that has capacity to substitute wheat in bread flour in Egypt, includes barley, maize, rice and sorghum The recent study was carried out to determine the possibility of substituting local wheat varieties flour with rice, sorghum and naked barley flours. Rice flour substitution blends versus sorghum flour substitution blends contained significantly higher 1.396 protein units in Misr2 cultivar, 0.469 units in Giza171 cultivar and significant 0.016 units in Gimmeza11 cultivar. In the meantime, the difference between flour blends that contained rice flour substitution and those contained barley flour substitution in protein content were reduction of 1.899 units in Misr2 cultivar, 0.526 units in Giza171 cultivar and 0.484 units in Gimmeza11 cultivar. Meanwhile, the influence of fenugreek flour in blends to protein content showed that, less protein content was associated with fenugreek substitution relative soybean. That reduction reached 0.129 units in Misr2, 0.158 units in Giza171 and 0.137 units in Gimmeza11 cultivar. Substitution of wheat flour by rice flour in blends resulted in significant increase in dry gluten percentage of Misr2 cultivar reached $0.056 \%$ over blends with sorghum flour. While, blends of Giza 171 had significantly $0.233 \%$ lower dry gluten. Also, rice/Gimmeza11 flour blends showed insignificantly $0.010 \%$ lower dry gluten percentage relative to blends with sorghum flour. Wheat blends with rice flour in comparison to blends with barley flour, indicated a reduction in dry gluten percentage reached $-0.027,-0.332$ and -0.227 for wheat cultivars Misr2, Giza171 and Gimmeza11, respectively. Blend contained substitution with 5\% fenugreek flour and 5\% soybean flour contained significantly less $0.078,0.251$ and $0.084 \%$ dry gluten in comparison to blends that contained a substitution of $5 \%$ fenugreek for cultivars, Misr2, Giza171 and Gimmeza11, respectively.
\end{abstract}

Key words: Substitution, wheat flour, local cereals, pulses flour, Flour protein, dry gluten content.

\section{INTRODUCTION}

Among the cultivated cereals, wheat has a unique nourishment position. This simply goes to the type of starch it contain, it is content of protein ,minerals, vitamins and fat (Ereifej et al.2006). Dough produced from wheat flour different from those made from other cereals in their viscoelastic properties. The raised bread loaf is possible because the wheat kernel contain gluten, an elastic form of protein that trap minute bubbles of carbon dioxide when fermentation occurs in leavened dough causing the dough to rise (Popa et al 2014).

Wheat cultivars within species differ in grain composition and quality of processing. The later gained more importance in grain trade which reflects grains attributes associated with processing quality. Grain protein content varies between 8 and 17 percent, depending on genetic make-up and production factors. The insoluble protein form in wheat flour when come to contact with water,shows the viscoelastic mass of gluten, which represents about 78 to 85 percent of total wheat endosperm protein. This type of protein is complex composed of polymeric and monomeric proteins known as glutenins and gliadins. Glutenins confer elasticity, while, gliadins confer mainly viscous flow and extensibility. This is how gluten is responsible for vescoelastic properties of wheat- flour dough. It is also the main character dictating the proper use of wheat variety. Gluten viscoelasticity for end -use purposes is commonly known as flour or dough strength. (Qarooni et al,1987). Roughly, wheat flour contains the same amounts of glutenins and gliadins . The unbalance of glutein/gliadin ratio may change the vescoelastic properties. The fraction of gluten is, however, the major protein factor responsible for variation in dough strength among wheat varieties (Rozylo and.Laskowski,2011).

In Egypt, bread is traditionally produced from wheat "'triticum aestivum" flour. Due to high demand, about $50 \%$ of needed wheat is imported. The inability to sustain the national wheat imports for making wheat based foods, makes is imperative that some substitutes for wheat must be incorporated in the bread preparation. Using alternate flour in bread making was introduced many years ago. Many of tested wheat blends showed levels of success in bread making (Harden and 
Yang,1975;D'Appolonia,1977).Local non wheat flours were used in replacing portions of wheat flour in bread making worldwide (Okaka and Potter, 1977).

Alternative non wheat cereals that has capacity to substitute wheat in bread flour in Egypt, includes barley, maize, rice and sorghum .Maize 'Zea mays' is rich in energy and good quality protein but, the pericarp fraction, which contain $77.7-84.6 \%$ dietary fiber (Gupta and Singh, 1981), adheres tightly to the outer surface of aleuron layer, so that, cannot be removed easily and become responsible for decreasing digestibility and smoothness of dough. Finally, produce Fast staled bread. Rice "Oryza sativa" is the second cereal crop in Egypt after wheat. Regarding the total produced quantity; 9.46 and 5.72 million tons for wheat and rice ,respectively (year book of agricultural statistics,2016) A large quantity of broken rice grains result during the processing of rice which amount to 500.000 tons annually. The nutritional contribution of rice flour goes to its content of amylase protein and low molecular weight sugar.

Naked barley "Hordeum vulgar" is proposed as an alternative to wheat cultivation in marginal land of Egypt and under limited water allowances. Besides, the required processing and milling techniques are similar for wheat and barley. The total produced quantity of barley grains reach 130,000 ton most of it is covered grains.

Sorghum "Sorghum bicolor" is an obligate cereal to upper Egypt, where, climatic condition enable yield proliferation and people consume sorghum bread.A total of one million ton of sorghum grains is produced annually (year book of agriculture statistics, 2016).

Legumes flours are blended with wheat flour at variable ratios to increase water absorption and reducing dough stability in Farinograph. Many researches scored an increase in water absorption with each increase in dough's protein level. (Matz, 1972 and Younis, 2014). Simon, 1987, stated that high water absorption flour produce high quality bread, with long shelf-life. Also, low protein dough (less than 12\%) has long development time (Finncy et al, 1987). Composite flour technology entails reaching high quality products at an economic level. This might be attained by mixing defatted soy flour (Junqueira et al, 2000 and Hosny, 2018) or lupine flour (Hull and Johnson, 2004).

The recent study was carried out to determine the possibility of substituting local wheat varieties flour with rice, sorghum and naked barley flours in relation to protein and dry gluten content.

\section{MATERIALS AND METHODES}

The recent study included studying the possibility of substituting local cereals flours (rice, sorghum and naked barley) to local bread wheat cultivars. Adding fenugreek local pulse flour and imported soybean flour to improve characters of bread was also included. Separate experiments were carried out for each bread wheat variety(three experiments). The studied local bread wheat cultivars were; Misr 2, Giza 171 and Gemmiza 11.Row materials for local cereals, fenugreek and bread wheat cultivars were obtained from the Agricultural Research center, Ministry of Agriculture, Giza, Egypt. 86\% extraction flour were prepared following AACC; 26-10 A method. Tempered cleaned grains milled by barabender quadrumat mill using the barabender procedure. For each local bread wheat cultivars the following flour blends were prepared (Table1).

Flour Quality

The studied flour blends were subject to the following determination:

- Crude protein percentage; determined according to AACC.38-12.02, 2000.

- Gluten content; Determined according to AACC 38-12.02, 2000.

Statistical analysis:

MSTAT-C package (1986) was used. Numerical data were subjected to square root transformation before analysis. Separate experiments was analyzed them combined analysis was performed when the assumption of error homogeneity cannot be rejected (Bartllet, 1937). Orthogonal comparisons were used to compare selected groups of treatments.

\section{RESULTS AND DISCUSSION}

The main objective of the recent study was to assess the possibility of substituting local cereals flours represented by rice, sorghum and naked barley to wheat flour. Three separate experiments were carried out each included one of the local bread wheat varieties. These were Misr2, Giza171 and Gimmiza11. Combined analysis of experiments (cultivars) was performed. Since, the assumption of homogeneity of variances was not rejected. The obtained results were presented for flour chemical analysis and.

Table 2 illustrated mean squares of flour protein and dry gluten content over the three wheat cultivars. Crude protein percentage were significantly $(\mathrm{p} \geq 0.01)$ different among the studied cultivars. In the meantime, the studied flour blends were significantly $(\mathrm{p} \geq 0.01)$ different in all studied chemical analysis characters. Also, significant $(p \geq 0.01)$ interaction between varieties and flour blends were reached in crude protein percentage. 
Table 1: list of studied flour blends that represent different levels of local cereals flour substitution and pulse flour addition

\begin{tabular}{|c|c|c|c|c|}
\hline \multirow{2}{*}{ code } & \multirow{2}{*}{ Treatment } & \multicolumn{3}{|c|}{ Component of one kilogram blended flour } \\
\hline & & wheat & cereal & pulse \\
\hline 1 & WF $100 \%$ & 1000 & - & - \\
\hline 2 & $\mathrm{WF}+10 \% \mathrm{RF}$ & 900 & 100 & - \\
\hline 3 & $\mathrm{WF}+10 \% \mathrm{RF}+5 \% \mathrm{Fen}$ & 850 & 100 & 50 \\
\hline 4 & $\mathrm{WF}+10 \% \mathrm{RF}+5 \%$ So & 850 & 100 & 50 \\
\hline 5 & $\mathrm{WF}+20 \% \mathrm{RF}$ & 800 & 200 & - \\
\hline 6 & $\mathrm{WF}+20 \% \mathrm{RF}+5 \% \mathrm{Fen}$ & 750 & 200 & 50 \\
\hline 7 & $\mathrm{WF}+20 \% \mathrm{RF}+5 \%$ So & 750 & 200 & 50 \\
\hline 8 & $\mathrm{WF}+30 \% \mathrm{RF}$ & 700 & 300 & - \\
\hline 9 & $\mathrm{WF}+30 \% \mathrm{RF}+5 \%$ Fen & 650 & 300 & 50 \\
\hline 10 & $\mathrm{WF}+30 \% \mathrm{RF}+5 \%$ So & 650 & 300 & 50 \\
\hline 11 & $\mathrm{WF}+10 \% \mathrm{SF}$ & 900 & 100 & - \\
\hline 12 & $\mathrm{WF}+10 \% \mathrm{SF}+5 \% \mathrm{Fen}$ & 850 & 100 & 50 \\
\hline 13 & $\mathrm{WF}+10 \% \mathrm{Sf}+5 \%$ So & 850 & 100 & 50 \\
\hline 14 & $\mathrm{WF}+20 \% \mathrm{SF}$ & 800 & 200 & - \\
\hline 15 & $\mathrm{WF}+20 \% \mathrm{SF}+5 \% \mathrm{Fen}$ & 750 & 200 & 50 \\
\hline 16 & $\mathrm{WF}+20 \% \mathrm{SF}+5 \%$ So & 750 & 200 & 50 \\
\hline 17 & $\mathrm{WF}+30 \% \mathrm{SF}$ & 700 & 300 & - \\
\hline 18 & $\mathrm{WF}+30 \% \mathrm{SF}+5 \% \mathrm{Fen}$ & 650 & 300 & 50 \\
\hline 19 & $\mathrm{WF}+30 \% \mathrm{SF}+5 \%$ So & 650 & 300 & 50 \\
\hline 20 & $\mathrm{WF}+10 \% \mathrm{BF}$ & 900 & 100 & - \\
\hline 21 & $\mathrm{WF}+10 \% \mathrm{BF}+5 \%$ Fen & 850 & 100 & 50 \\
\hline 22 & $\mathrm{WF}+10 \% \mathrm{BF}+5 \%$ So & 850 & 100 & 50 \\
\hline 23 & $\mathrm{WF}+20 \% \mathrm{BF}$ & 800 & 200 & - \\
\hline 24 & $\mathrm{WF}+20 \% \mathrm{BF}+5 \% \mathrm{Fen}$ & 750 & 200 & 50 \\
\hline 25 & $\mathrm{WF}+20 \% \mathrm{BF}+5 \%$ So & 750 & 200 & 50 \\
\hline 26 & $\mathrm{WF}+30 \% \mathrm{BF}$ & 700 & 300 & - \\
\hline 27 & $\mathrm{WF}+30 \% \mathrm{BF}+5 \%$ Fen & 650 & 300 & 50 \\
\hline 28 & $\mathrm{WF}+30 \% \mathrm{BF}+5 \%$ So & 650 & 300 & 50 \\
\hline 29 & $\mathrm{WF}+5 \%$ Fen & 950 & - & 50 \\
\hline 30 & $\mathrm{WF}+5 \%$ So & 950 & - & 50 \\
\hline 31 & WF+5\%Fen+5\%So & 900 & - & 100 \\
\hline
\end{tabular}

WF; Wheat flour $\quad$ RF; Rice flour $\quad$ SF; Sorghum flour $\quad$ BF; Barley flour

Fen; Fenugreek flour SO; Soybean flour

Table 2: Mean squares of protein percentage and dry gluten content of flour blends as affected by wheat cultivar and cearles and / or pulse flour blends.

\begin{tabular}{|c|c|c|c|}
\hline \multirow{2}{*}{ S.O.V. } & \multirow{2}{*}{ d.f. } & \multicolumn{2}{|c|}{ M.S. } \\
\hline & & Protein (dry base) & Dry gluten \\
\hline Wheat cultivar (A) & 2 & $285.150^{* *}$ & $85.411^{\mathrm{n} . \mathrm{s}}$ \\
\hline Error & 4 & 0.056 & 3.671 \\
\hline Flour blends (B) & 30 & $11.025^{* *}$ & $5.573^{* *}$ \\
\hline $\mathrm{A} \times \mathrm{B}$ & 60 & $4.478^{* *}$ & $0.836^{* *}$ \\
\hline Error & 180 & 0.027 & 0.290 \\
\hline \multicolumn{2}{|c|}{$\begin{array}{l}\text { A: Protein content (dry base): } \\
\text { Rice flour substitution: } \\
\quad \text { Rice flour substitution to wheat flour } \\
\text { significantly affected protein content of the flour } \\
\text { blends (Table } 2 \text { ). Overall the studied cultivars, the } \\
\text { highest significant protein content was expressed by }\end{array}$} & \multicolumn{2}{|c|}{$\begin{array}{l}\text { significant rank was represented by wheat flour }+ \\
10 \% \text { rice flour }+5 \% \text { Fenugreek flour blend }(9.989) \text {. } \\
\text { Significantly lower third rank in protein content was } \\
\text { presented by wheat flour }+10 \% \text { rice flour blend } \\
(9.744) \text {. The fourth significant rank expressed by } \\
\text { wheat flour }+30 \% \text { rice flour bland }(9.206) \text {. }\end{array}$} \\
\hline
\end{tabular}

wheat flour (10.33) and wheat flour $+10 \%$ rice flour

$+5 \%$ soybean flour blend (10.44). The second 
Table 3: Effect of rice flour and pulses flour substitution on protein content (dry base) of flour blends of wheat cultivars.

\begin{tabular}{|c|c|c|c|c|}
\hline \multirow{2}{*}{ Flour blends } & \multicolumn{4}{|c|}{ Wheat cultivar } \\
\hline & Misr2 & Giza171 & Gimmeza11 & Combined \\
\hline WF $100 \%$ & 9.283 & 11.057 & 10.657 & $10.332^{\mathrm{a}}$ \\
\hline $\mathrm{WF}+10 \% \mathrm{RF}$ & 9.100 & 10.867 & 9.267 & $9.744^{\mathrm{c}}$ \\
\hline $\mathrm{WF}+10 \% \mathrm{RF}+5 \%$ Fen & 9.517 & 11.413 & 9.037 & $9.989^{\mathrm{b}}$ \\
\hline WF $+10 \%$ RF+ $5 \%$ Soy & 10.403 & 12.257 & 8.660 & $10.440^{\mathrm{a}}$ \\
\hline $\mathrm{WF}+20 \% \mathrm{RF}$ & 8.067 & 9.610 & 8.263 & $8.647^{\mathrm{f}}$ \\
\hline $\mathrm{WF}+20 \% \mathrm{RF}+5 \%$ Fen & 8.333 & 10.113 & 7.250 & $8.566^{\mathrm{f}}$ \\
\hline $\mathrm{WF}+20 \% \mathrm{RF}+5 \%$ Soy & 9.333 & 10.633 & 7.207 & $9.058^{\mathrm{e}}$ \\
\hline $\mathrm{WF}+30 \% \mathrm{RF}$ & 8.500 & 10.190 & 8.927 & $9.206^{\mathrm{d}}$ \\
\hline $\mathrm{WF}+30 \% \mathrm{RF}+5 \%$ Fen & 9.327 & 10.820 & 6.933 & $9.027^{\mathrm{e}}$ \\
\hline $\mathrm{WF}+30 \% \mathrm{RF}+5 \%$ Soy & 10.430 & 11.840 & 6.870 & $9.713^{\mathrm{c}}$ \\
\hline Mean & $9.2296^{\mathrm{b}}$ & $10.88^{\mathrm{a}}$ & $8.307^{\mathrm{c}}$ & \\
\hline
\end{tabular}

That previous blend was paradoxically superior to the blend of wheat flour $+30 \%$ rice flour $+5 \%$ Fenugreek flour (9.027). Also, that latter blend was significantly similar to the blend of wheat flour + $20 \%$ rice flour $+5 \%$ soybean flour (9.059). The least significant protein content was expressed by any of wheat flour $+20 \%$ rice flour blend $+5 \%$ Fenugreek flour (8.647 and 8.566, respectively).

Commonly, disharmony in protein content of various blends overall the studied wheat cultivars, was mainly affected by the significant cultivar $\mathrm{x}$ blend interaction, since, the behavior of blends varied in magnitude or trend of change with variable wheat cultivar. This might explain the failure of flour blends that contained pulses flour to show higher values of protein content. The previous assumption might be clarified when considering the highest significant protein content that expressed by the blend of Giza171 flour $+10 \%$ rice flour $+5 \%$ soybean flour (12.26). The second significant rank of protein content was expressed by the blend of the same wheat cultivar flour $+30 \%$ rice flour $+5 \%$ soybean flour (11.84). While, the least significant protein content was presented Gimmeza11 wheat flour cultivar blends with $30 \%$ rice flour irrespective of the type of pulse flour $(6.933$ and 6.870 for wheat flour $+30 \%$ rice flour $+5 \%$ Fenugreek flour blend and wheat flour $+30 \%$ rice flour $+5 \%$ soybean flour blend, respectively). It was valuable to notice that, overall the studied flour blends, Giza171 cultivar exhibited the highest significant protein content (10.88), whereas, Gimmaza11 cultivar presented the least mean protein content (8.307).

Orthogonal comparisons that summarize the effect of rice flour substitution level on wheat flour blend's protein content were presented in Table 4. Increasing the level of rice flour substitution from $10 \%$ to $20 \%$ of the flour bland was associated with an increase in protein content reached 0.548 $(\mathrm{p} \geq 0.0001), 0.029(\mathrm{p} \geq 0.0001)$ and $0.707(\mathrm{p} \geq 0.0001)$ for wheat cultivars Misr2, Giza171 and Gimmeza11 cultivars, respectively. Also, increasing the level of rice flour substitution to wheat flour from $20 \%$ to $30 \%$ was associated with negative affection protein content reached $0.421(\mathrm{p} \geq 0.0001), 0.416(\mathrm{p} \geq 0.0001)$ and $0.002(\mathrm{p} \geq 0.003)$ for the three studied wheat cultivars; Misr2, Giza171 and Gimmeza11; respectively. Overall the studied wheat cultivars, an increase in protein content reached 0.430 ( $\mathrm{p} \geq 0.0001$ ) was associated with increasing rice flour substitution from $10 \%$ to $20 \%$. While, increasing the level of rice flour substitution, from $20 \%$ to $30 \%$ resulted in an overall decrease in protein content reached 0.281 ( $\mathrm{p} \geq 0.003)$.

\section{Sorghum flour substitution:}

Protein content (dry base) of flour blends representing different levels of sorghum flour substitution to wheat cultivars flours were presented in Table 5. Substitution of sorghum flour to Misr2 wheat flour was associated with clear increase in blend's protein content. Substituting 10\% of Misr2 flour with sorghum flour gave significantly rich blend in protein (9.283 and 9.613 for wheat and wheat $+10 \%$ sorghum flour blend, respectively). Substituting wheat flour with additional 5\% fenugreek flour gave significantly richer protein blend (10.657). Also, soybean flour substitution to Misr2 wheat flour at $5 \%$ gave significantly protein higher blend (11.433). Increasing sorghum flour substitution level to $20 \%$ wheat flour, gave significantly additional protein content. Pulses flour substitution gave variable effects to blend protein content. Where, fenugreek flour significantly raised protein content of the blend (12.40). While, soybean flour substitution yielded significantly lower protein content (12.00). 


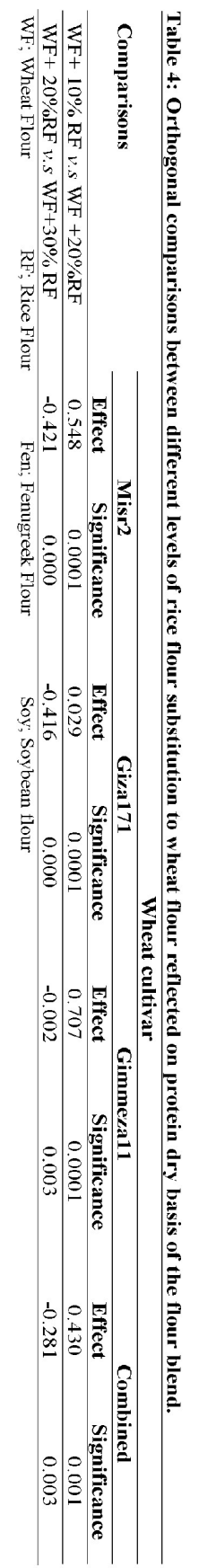


The highest protein content in flour blends were those resulted from $30 \%$ sorghum flour substitution with significantly similar figures irrespective of pulses flour substitution $(13.34,13.33$ and 13.17 for wheat flour $+30 \%$ sorghum flour substitution, wheat flour $+30 \%$ sorghum flour $+5 \%$ fenugreek flour and wheat flour $+30 \%$ sorghum flour $+5 \%$ soybean flour blends, respectively). Protein content of Giza171 wheat cultivar blends in response to sorghum flour substitution were in harmony to those presented in Misr2 cultivar. 10\% sorghum flour substitution to wheat flour gave significantly higher protein content relative to wheat flour (11.06 and 11.27 for the former and the latter, respectively). Additional substitution to another $5 \%$ by fenugreek and soybean flours gave significantly higher protein content. In the meantime, blends contained fenugreek or soybean flour were significantly different with superiority to soybean flour (11.75 and 12.78 for fenugreek and soybean blends, respectively). It was valuable to notice that increasing the level of sorghum flour substitution to $20 \%$ gave blend of significantly higher protein content relative to wheat flour (10.35) but, was relatively and significantly of lesser protein content relative to blend that contained only $10 \%$ sorghum flour substitution to wheat flour. Additional substitution of $5 \%$ fenugreek flour gave a blend of significantly higher protein content (10.80). Replacing fenugreek flour by soybean flour at the same level 5\% was associated with significant increase in protein content (11.87). Blend that has $30 \%$ sorghum flour substitution had protein content significantly surpassed $20 \%$ sorghum wheat flour blend (12.10). Additional substitution by $5 \%$ fenugreek flour gave significantly similar protein content (12.00). Wheat flour with 30\% sorghum flour $+5 \%$ soybean flour blend significantly enjoyed the highest protein content of 13.27.
As for Gimmeza11 wheat cultivar, sorghum flour substitution was proportionally associated with reduction in protein content. Wheat flour blends that contained $20 \%$ sorghum flour contained about three unit of protein content, relative to pure wheat flour. Additional substitution by $5 \%$ fenugreek or soybean flour gave significantly lower protein content of flour blends (7.443 and 7.440 for blends of wheat flour $+30 \%$ sorghum flour $+5 \%$ fenugreek flour and wheat flour $+30 \%$ sorghum flour $+5 \%$ soybean flour, respectively). The least protein content were presented by blends of wheat flour $+30 \%$ sorghum flour $+5 \%$ fenugreek or soybean flours (7.250 and 7.177, respectively). It was valuable to notice that, the significant interaction between wheat cultivar and flour blends was mainly due to the variable magnitude of protein content in similar blends of variable cultivars and the disharmony in the pattern of protein content response to variation in the level of sorghum flour substitution. In the meantime overall wheat cultivar blends, Misr2 and Giza171 showed similar protein content that were significantly superior to Gimmeza11 cultivar (11.74, 11.73 and 8.335 , respectively).

Orthogonal comparison between different levels of sorghum flour substitution to wheat flour reflected on protein (dry base) of flour blend were presented in Table 6 . Overall the studied flour blends, $10 \%$ versus $20 \%$ sorghum flour substitution was associated with a reduction of 0.186 unit in protein content of Misr2 wheat flour ( $\mathrm{p} \geq 0.0001$ ), an increase of 0.464 unit in Giza171 wheat cultivar $(\mathrm{p} \geq 0.0001)$ and an increase of 0.855 unit in Gimmeza11 wheat cultivar $(\mathrm{p} \geq 0.0001)$. Over the three studied wheat cultivar, the rise in sorghum flour substitution from 10to $20 \%$ was associated with an increase of 0.410 unit ( $\mathrm{p} \geq 0.001)$.

Table 5: Effect of Sorghum flour and pulses Flour substitution on protein (dry base) of flour blends of wheat cultivars.

\begin{tabular}{lcccc}
\hline \multirow{2}{*}{ Flour blends } & \multicolumn{4}{c}{ Wheat cultivar } \\
\cline { 2 - 5 } & Misr2 & Giza171 & Gimmeza11 & Combined \\
\hline WF $100 \%$ & 9.283 & 11.06 & 10.657 & 10.332 \\
\hline WF+ 10\% SF & 9.613 & 11.27 & 9.663 & 10.183 \\
\hline WF+10\% SF+ 5\% Fen & 10.657 & 11.75 & 9.097 & 10.500 \\
\hline WF+10\% SF+ 5\% Soy & 11.433 & $12.78^{\mathrm{b}}$ & 9.152 & 11.122 \\
\hline WF+ 20\% SF & 12.200 & 10.35 & 7.900 & 10.149 \\
\hline WF+ 20\% SF+ 5\% Fen & $12.400^{\mathrm{c}}$ & 10.80 & 7.443 & 10.213 \\
\hline WF+ 20\% SF+ 5\% Soy & $12.000^{\mathrm{d}}$ & 11.87 & 7.440 & 10.438 \\
\hline WF+ 30\% SF & $13.340^{\mathrm{a}}$ & $12.10^{\mathrm{d}}$ & 7.573 & 11.004 \\
\hline WF+ 30\% SF+ 5\% Fen & $13.33^{\mathrm{a}}$ & $12.00^{\mathrm{d}}$ & 7.250 & 10.861 \\
\hline WF+ 30\% SF+ 5\% Soy & $13.17^{\mathrm{a}}$ & $13.27^{\mathrm{a}}$ & 7.177 & 11.206 \\
\hline Mean & 11.74 & 11.73 & 8.335 & \\
\hline WF; Wheat Flour SF; Sorghum Flour & Fen; Fenugrek Flour & Soy; Soybean flour
\end{tabular}

WF; Wheat Flour SF; Sorghum Flour $\quad$ Fen; Fenugreek Flour $\quad$ Soy; Soybean flour

L.S.D. cultivar ${ }_{0.01} ; 0.1085$

L.S.D. blends ${ }_{0.01} ; 0.1549$

L.S.D. interaction; 0.2683 


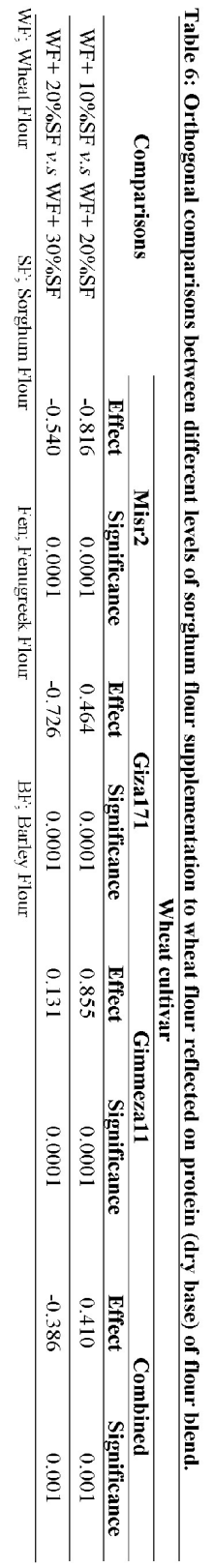


Additional increase in level of sorghum flour substitution (20 versus 30\% levels) gave reduced protein content by 0.540 unit $(p \geq 0.0001)$ in Misr2 cultivar, 0.726 unit $(\mathrm{p} \geq 0.0001)$ in Giza171. Meanwhile, increased protein content by 0.131 unit $(p \geq 0.0001)$ in Gimmeza11 wheat cultivar. Over the three studied cultivar, raising the level of sorghum substitution gave a false indication of protein content reduction of 0.386 units, since, the cultivars blends interaction was significant.

\section{Barley flour substitution:}

Barley flour substitution to wheat flour blends and additional substitution by pulses flours effects to protein content (dry base) were presented in Table 7. As for Misr2 wheat flour, $10 \%$ barley flour substitution gave significantly higher levels of protein in flour blends. Additional substitution by $5 \%$ fenugreek or soybean flours adversely affected protein content $(9.283,13.55,13.35$ and 13.29 for wheat flour, wheat flour $+10 \%$ barley flour, wheat flour $+10 \%$ barley flour $+5 \%$ fenugreek flour and wheat flour $+10 \%$ barley flour $+5 \%$ soybean flour, respectively).

The magnitude of increase in protein content when barley flour substitution reached $20 \%$ was of lesser magnitude relative to $10 \%$ substitution level. In the meantime, protein content of $20 \%$ barley flour level blends had significantly similar protein content $(12.23,12.33$ and 12.23 for wheat flour + $20 \%$ barley flour, wheat flour $+20 \%$ barley flour + $5 \%$ fenugreek flour and wheat flour $+20 \%$ barley flour $+5 \%$ soybean flour, respectively). $30 \%$ barley flour substitution in wheat flour blends was associated with further increase in protein content. Additional substitution by $5 \%$ fenugreek flour gave significant superiority in protein content relative to pulse-free blend (13.28 and 13.59 for wheat flour + $30 \%$ barley flour and wheat flour $+30 \%$ barley flour $+5 \%$ fenugreek flour blends, respectively).
Substituting $5 \%$ soybean flour to wheat $+30 \%$ barley flour blend gave significantly similar protein content (13.34). Regarding Giza171 wheat cultivar, blends that contained pulse flour significantly surpassed pulse-free barley/ wheat blend at $10 \%$ level of substitution and pure wheat flour. Blends that contained $20 \%$ barley flour showed lower protein content relative to $10 \%$ level of barley substitution blends. Inclusion of pulses flours in the blends were associated with a relative increase in protein content. At 30\% level of barley flour substitution, the highest magnitude of grains in protein content in blends were recorded. Additional substitution of 5\% soybean flour gave 13.46 protein content which was the largest figure among the blends.

Concerning Gimmeza11 wheat cultivar, pure wheat flour expressed protein content, significantly higher than those recorded for $10 \%$ barley flour substitution with lesser values when pulses flours were included. Raising the level of barley flour substitution to $20 \%$ or $30 \%$ were associated with reduction in protein content. Overall the studied blends Misr2 flours enjoyed significantly higher protein content amounted 12.65 followed by Giza171 (11.83) then Gimmeza11 (9.178).

Orthogonal comparison between blends that contained $10 \%$ barley flour substitution and those contained $20 \%$ barley flour (Table 8) cleared that raising the level of barley in flour blend of Misr2 gave an increase in protein content of 0.566 units $(\mathrm{p} \geq 0.0001)$. Whereas, Giza171 and Gimmeza11 scored $0.375(p \geq 0.0001)$ and $0.434(p \geq 0.0001)$, respectively. While the difference between flour blends of $20 \%$ barley flour and $30 \%$ barley flour in protein content reached $-0.568(\mathrm{p} \geq 0.0001),-0.751$ $(\mathrm{p} \geq 0.0001)$ and $-0.354 \quad(\mathrm{p} \geq 0.0001)$ for Misr2, Giza171 and Gimmeza11, respectively).

Table 7: Effect of barley flour and pulses flour substitution on protein (dry base) of flour blends of wheat cultivars.

\begin{tabular}{|c|c|c|c|c|}
\hline \multirow{2}{*}{ Flour blends } & \multicolumn{4}{|c|}{ Wheat cultivar } \\
\hline & Misr2 & Giza171 & Gimmeza11 & Combined \\
\hline WF $100 \%$ & 9.283 & 11.057 & 10.657 & 10.332 \\
\hline $\mathrm{WF}+10 \% \mathrm{BF}$ & 13.550 & 11.030 & 9.607 & 11.396 \\
\hline $\mathrm{WF}+10 \% \mathrm{BF}+5 \%$ Fen & 13.350 & 11.663 & 9.247 & 11.420 \\
\hline $\mathrm{WF}+10 \% \mathrm{BF}+5 \%$ Soy & 13.293 & 13.040 & 9.213 & 11.849 \\
\hline $\mathrm{WF}+20 \% \mathrm{BF}$ & 12.233 & 10.443 & 7.940 & 10.206 \\
\hline $\mathrm{WF}+20 \% \mathrm{BF}+5 \%$ Fen & 12.333 & 10.983 & 9.923 & 11.080 \\
\hline $\mathrm{WF}+20 \% \mathrm{BF}+5 \%$ Soy & 12.233 & 12.057 & 7.600 & 10.630 \\
\hline $\mathrm{WF}+30 \% \mathrm{BF}$ & 13.283 & 11.917 & 7.710 & 10.970 \\
\hline $\mathrm{WF}+30 \% \mathrm{BF}+5 \%$ Fen & 13.59 & 12.617 & 12.380 & 12.861 \\
\hline $\mathrm{WF}+30 \% \mathrm{BF}+5 \%$ Soy & 13.337 & 13.457 & 7.497 & 11.430 \\
\hline Mean & 12.65 & 11.83 & 9.178 & \\
\hline
\end{tabular}

WF; Wheat Flour $\quad$ BF; Barley Flour $\quad$ Fen; Fenugreek Flour $\quad$ Soy; Soybean flour

L.S.D. cultivar ${ }_{0.01} ; 0.1085$

L.S.D. interaction; 0.2683 


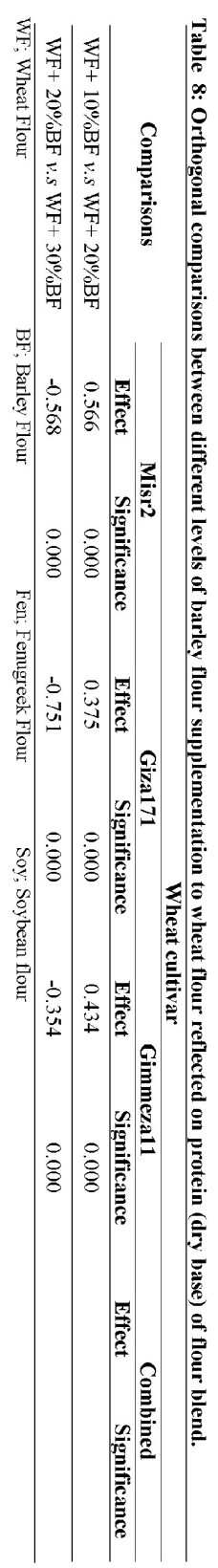


Overall role of local cereals:

Comparisons between blends that contain different cereals in protein content were presented in (Table 9). Rice flour substitution blends versus sorghum flour substitution blends contained significantly higher 1.396 units in Misr2 cultivar, 0.469 unit $(\mathrm{p} \geq 0.0001)$ in Giza171 cultivar and significant 0.016 unit in Gimmeza1 1 cultivar. In the meantime, the difference between flour blends that contained rice flour substitution and those contained barley flour substitution in protein content were reduction of $1.899(\mathrm{p} \geq 0.0001)$ units in Misr2 cultivar, 0.526 units ( $\mathrm{p} \geq 0.0001)$ in Giza171 cultivar and 0.484 units $(\mathrm{p} \geq 0.0001)$ in Gimmeza11 cultivar.

Overall role of pulses flour:

Table 10 illustrated orthogonal comparisons between blends that contain different pulse flours. Wheat flour / cereal flour / fenugreek blends with soybean flour had significantly lower protein content reached 0.150 unit in Misr2 cultivar, 0.513 unit in Giza171 cultivar and higher protein content in Gimmeza11 cultivar reached 0.386 units. In the meantime the comparison between blends that contained soybean and fenugreek flours versus those contained fenugreek showed that soybean flour blends had lower protein content reached 0.157 units in Misr2, 0.251 unit in Giza 171 and 0.067 unit in Gimmeza11. Meanwhile, the influence of fenugreek flour in blends to protein content showed that, less protein content was associated with fenugreek substitution relative soybean. That reduction reached 0.129 unit in Misr2, 0.158 unit in Giza171 and 0.137 unit in Gimmeza1 1 cultivar.

\section{2-1- Dry gluten:}

Dry gluten content of different studied flour blends as affected by rice flour substitution were presented in Table 11. Over the studied wheat cultivars, gluten content of the different flour blends were significantly lower than the recorded value for wheat flour $(8.111 \%)$ substitution with $10 \%$ rice flour gave significantly lower gluten percentage $(7.493 \%)$. Additional substitution with any of fenugreek or soybean flour, although, showed lower dry gluten percentage, that reduction had not reached the level of significance (7.20) and 7.339\% for $10 \%$ rice flour $+5 \%$ fenugreek flour and $10 \%$ rice flour $+5 \%$ soybean flour substitution, respectively). Rising the level of rice flour substitution to 20 or $30 \%$ gave significantly and similary lower dry gluten percentage of flour blends (6.210 and 6.459 $\%$ for each of 20 and $30 \%$ rice flour substitution blends, respectively). Also, further substitution by $5 \%$ fenugreek flour gave similary lower dry gluten percentage, irrespective of the level of rice flour substitution (5.760 and $5.810 \%$ for $20 \%$ rice flour + $5 \%$ fenugreek flour and $30 \%$ rice flour $+5 \%$ fenugreek flour substitution, respectively). Soybean flour substitution to rice flour + wheat flour blends gave insignificant increase in dry gluten percentage
(6.026 and $5.789 \%$ for $20 \%$ rice flour $+5 \%$ soybean flour and $30 \%$ rice flour $+5 \%$ soybean flour blends with wheat flour, respectively).

As for the interaction between blends and wheat cultivars, Giza171 cultivar flour scored a high magnitude figures of dry gluten, although, that superiority had not reached the level of significance (8.467, 8.367 and $7.500 \%$ for Giza171, Gimmeza11 and Misr2, respectively). That trend was observed for all studied wheat flour/ rice flour blends. In the meantime, dry gluten values presented by Misr2 wheat cultivar/rice flour blends were of lower magnitude. The highest dry gluten value was that of $10 \%$ rice flour $+5 \%$ soybean of Giza171 wheat cultivars flour substitution $(8.483 \%)$, whereas, the least value was presented by Misr2 wheat flour substitution with $30 \%$ rice flour $+5 \%$ soybean flour (4.700\%).

Table 12 reflected the effect of different levels of rice flour substitution to wheat flour on dry gluten percentage through orthogonal comparisons. Overall wheat cultivars and pulse flour substitution, $10 \%$ rice flour substitution showed significantly higher $(\mathrm{p} \geq 0.0001)$ dry gluten percentage over $20 \%$ substitution $(0.628,0.822$ and $0.569 \%$ for blends with Misr2, Giza171 and Gimmeza11 wheat cultivars, respectively). In the meantime, flour blends of Misr2 cultivar had 20\% rice flour had $0.189 \%$ higher dry gluten percentage $(p \geq 0.0001)$. Also, those of Giza171 and Gimmeza11 blends had insignificantly lower $(-0.264 \%)$ and higher $(+0.026 \%)$ dry gluten percentage, respectively.

\subsection{2; Sorghum flour substitution:}

Over the studied wheat cultivars, substitution of sorghum flour gave significantly lower dry gluten percentage Table $13.10 \%$ sorghum flour substitution to wheat flour wether alone or with additional substitution by any of 5\% fenugreek or sorghum flours scored significantly similar dry gluten percentage $(7.338,7.216$ and $7.458 \%$ for blends of $10 \%$ sorghum flour, $10 \%$ sorghum flour + $5 \%$ fenugreek flour and 10\% sorghum flour $+5 \%$ soybean flour, respectively). Increasing the level of sorghum flour substitution to 20 or $30 \%$ gave significantly lower and similar dry gluten percentages (about 6.00\%).

Regarding wheat cultivars $\times$ blends interaction Giza171 wheat blends, showed dry gluten percentages of relatively higher magnitude, while Misr2 wheat blends, showed relatively lower dry gluten percentages. The highest dry gluten values were presented by any of Giza 171 wheat flour or the blend of $20 \%$ sorghum flour $+5 \%$ soybean flour ( 8.467 and $8.617 \%$ respectively). Whereas, the least figures were shown by flour blends of Misr2 wheat cultivar that contained 20 or $30 \%$ sorghum flour alone or with $5 \%$ pulse flours (about $5.00 \%$ ). 


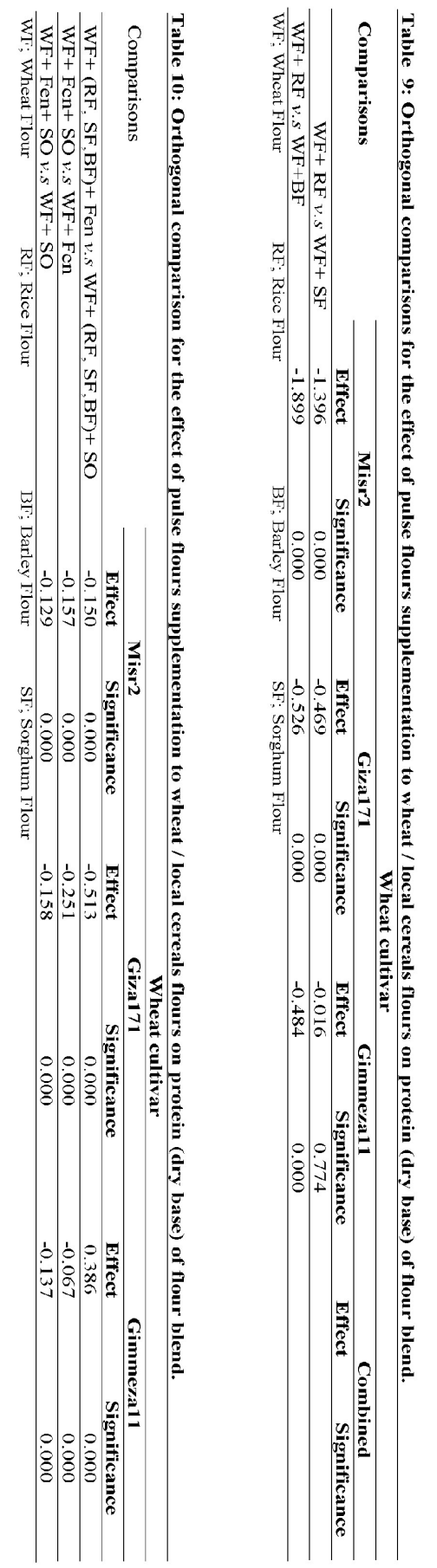




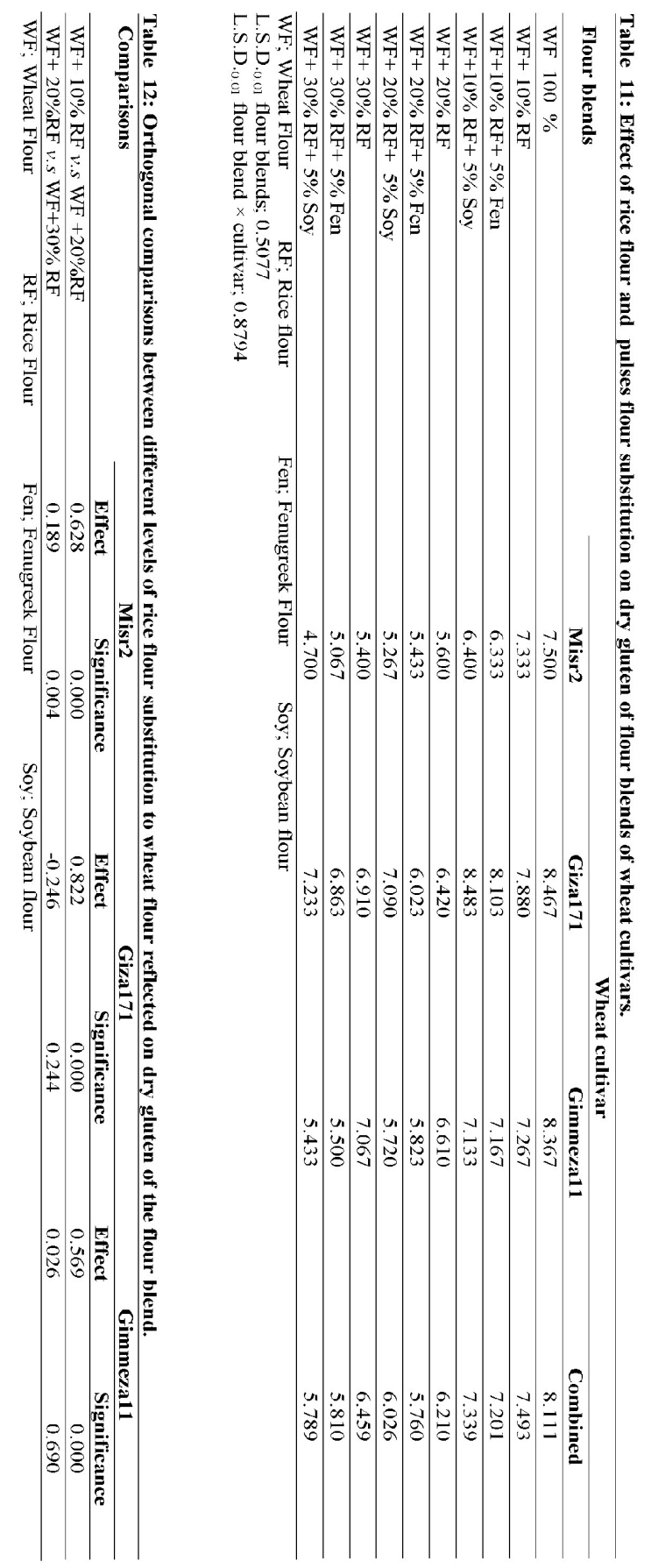




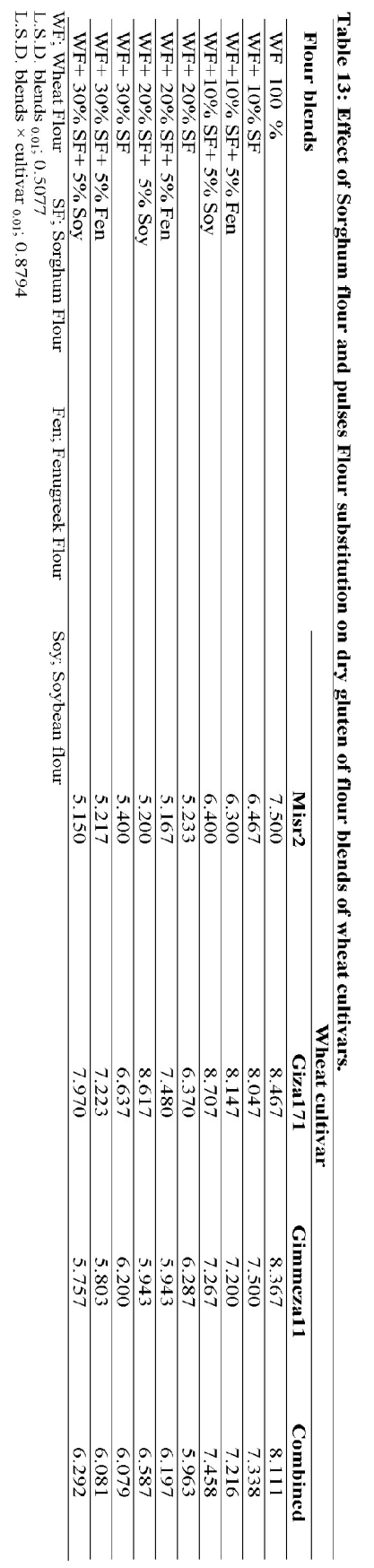


To clarify the role of sorghum flour substitution to wheat flour over the different blends, orthogonal comparisons (Table 14) showed that, 10\% sorghum flour substitution had higher levels of dry gluten relative to blends had $20 \%$ sorghum flours $(0.594$ and $0.632 \% \quad(p \geq 0.0001)$ for blends of Misr2 and Gimmeza11 wheat cultivars respectively). In Giza171 blends was insignificantly reached $0.406 \%$. Also, Misr2 flour blends that contained 20\% sorghum flour had insignificantly lower dry gluten percentage reached $-0.028 \%$ relative to flour blends that contained $30 \%$ sorghum flour. While, $20 \%$ sorghum flour blends of Giza171 wheat cultivar had insignificantly $0.106 \%$ dry gluten over $30 \%$ sorghum flour blends. Gimmeza11 flour blends with $20 \%$ sorghum flour had significantly $(\mathrm{p} \geq 0.02)$ higher $0.069 \%$ dry gluten percentage.

\subsection{3; Barley flour substitution:}

Table 15 showed the effect of barley flour and pulses flour substitution on dry gluten of flour blends. As an average over the three studied wheat cultivars, barley flour substitution was associated with significant reduction of flour dry gluten percentage, irrespective of the level of barley flour substitution (10 or 20 or $30 \%$ ). Wheat flour contained $8.111 \%$ dry gluten, whereas, flour blend contained $10 \%$ barley flour contained significantly similar dry gluten percentage of $7.530,7.191$ and $7.502 \%$ dry gluten for wheat/barley, wheat/barley $+5 \%$ fenugreek flour and wheat/ barley $+5 \%$ soybean flour, respectively. Significantly lower dry gluten percentage were associated with increasing the level of barley flour substitution to $20 \%$. Within the $20 \%$ barley flour blends, the highest magnitude of dry gluten with that of wheat flour $+20 \%$ barley flour + $5 \%$ soybean flour blend $(6.588 \%)$. A relatively insignificant rice in dry gluten percentage were marked with $30 \%$ barley flour blends being highest for wheat flour $+30 \%$ barley flour $+5 \%$ fenugreek flour $(7.158 \%)$.

The significant interaction between the studied wheat cultivar flour and the different blends was illustrated when considering the magnitude of dry gluten figures for different cultivars, since, Giza171 wheat cultivar showed relatively higher figures. In the meantime, the highest dry gluten percentages were provided by Giza 171 wheat flour $+10 \%$ barley flour $+5 \%$ soybean flour $(8.943 \%)$. In a time that the least figure was provided by any Misr2 wheat flour +20 or $30 \%$ barley flour $+5 \%$ any of fenugreek or soybean flour (about 5.4\%). In Misr2 flour blends, blends of various levels of barley flour substitution were significantly inferior to full wheat flour. While, all the studied Giza171 flour blends recorded variable insignificant increase in dry gluten percentage, except for, blends of $20 \%$ barley flour and $20 \%$ barley flour $+5 \%$ fenugreek flour that contained significantly lower dry gluten percentage (6.643 and $6.227 \%$, respectively).

Orthogonal comparisons between levels of barley flour substitution over pulse flours were presented in Table 16. Wheat flour blends substituted with $10 \%$ barley flour had significantly higher 0.493 (Misr2), 0.668 (Giza171) and 0.550 (Gimmeza11) dry gluten percentage over blends that substituted with $20 \%$ barley flour. Also, blends that contained $20 \%$ barley flour showed insignificantly $0.094 \%$ lower dry gluten (Mirs2), significantly lower $0.002 \%$ dry gluten (Giza 171) and significantly lower $0.120 \%$ dry gluten (Gimmeza11). In other words, increasing the level of barley flour substitution from 10 to $20 \%$ was associated with reduction in dry gluten percentage, while, increasing the substitution level from 20 to $30 \%$ barley flour was associated with an increase in dry gluten percentage.

Orthogonal comparisons between wheat/cereals blends were presented in Table 17. Substitution of wheat flour by rice flour in blends resulted in significant increase in dry gluten percentage of Misr2 cultivar reached $0.056 \%$ over blends with sorghum flour. While, blends of Giza171 had significantly $0.233 \%$ lower dry gluten. Also, rice/Gimmeza11 flour blends showed insignificantly $0.010 \%$ lower dry gluten percentage relative to blends with sorghum flour.

Also, wheat blends with rice flour in comparison to blends with barley flour, indicated a reduction in dry gluten percentage reached -0.027 $(\mathrm{p} \geq 0.561), \quad-0.332(\mathrm{p} \geq 0.008)$ and $-0.227(\mathrm{p} \geq 0.0001)$ for wheat cultivars Misr2, Giza171 and Gimmeza11, respectively.

\section{Role of pulse flour substitution:}

To illustrate the role of pulse flour substitution to dry gluten percentage of the studied flour blends, orthogonal comparisons were illustrated in Table 18. Fenugreek flour substitution to wheat flour in blends of Misr2 cultivar, gave unclear effect, while, caused significant reduction of $-0.437 \%$ in Giza171 cultivar and a significant raise of $0.147 \%$ to dry gluten percentage of Gimmeza11 cultivar. A blend contained substitution with 5\% fenugreek flour and $5 \%$ soybean flour contained significantly less 0.078 , 0.251 and $0.084 \%$ dry gluten in comparison to blends that contained a substitution of 5\% fenugreek for cultivars, Misr2, Giza171 and Gimmeza11, respectively. Also, the comparison between the group of blends that contained fenugreek and soybean flours versus those contained soybean flour revealed significant reduction in dry gluten percentage. the reduction in dry gluten percentage due to the substitution by two pulse flour rather than soybean flour reached $-0.078,-0.0172$ and $-0.111 \%$ for Misr2, Giza171 and Gimmeza11 cultivars, respectively. 


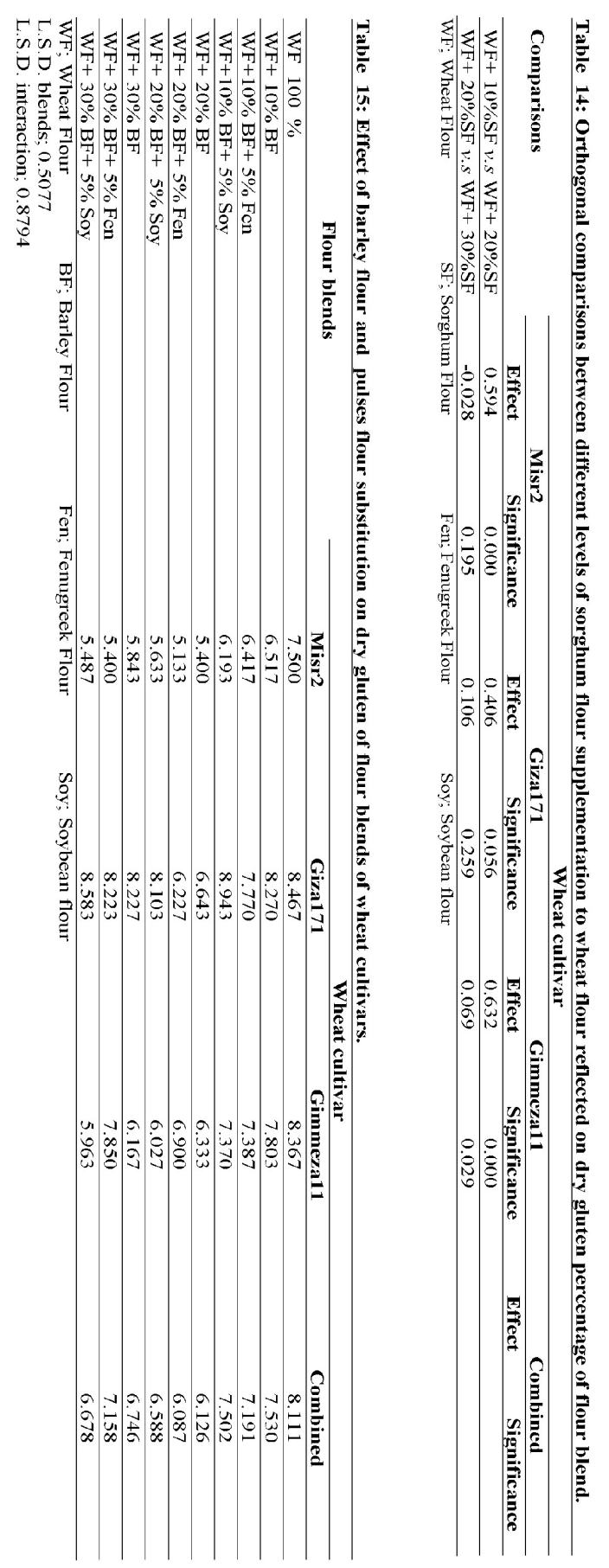




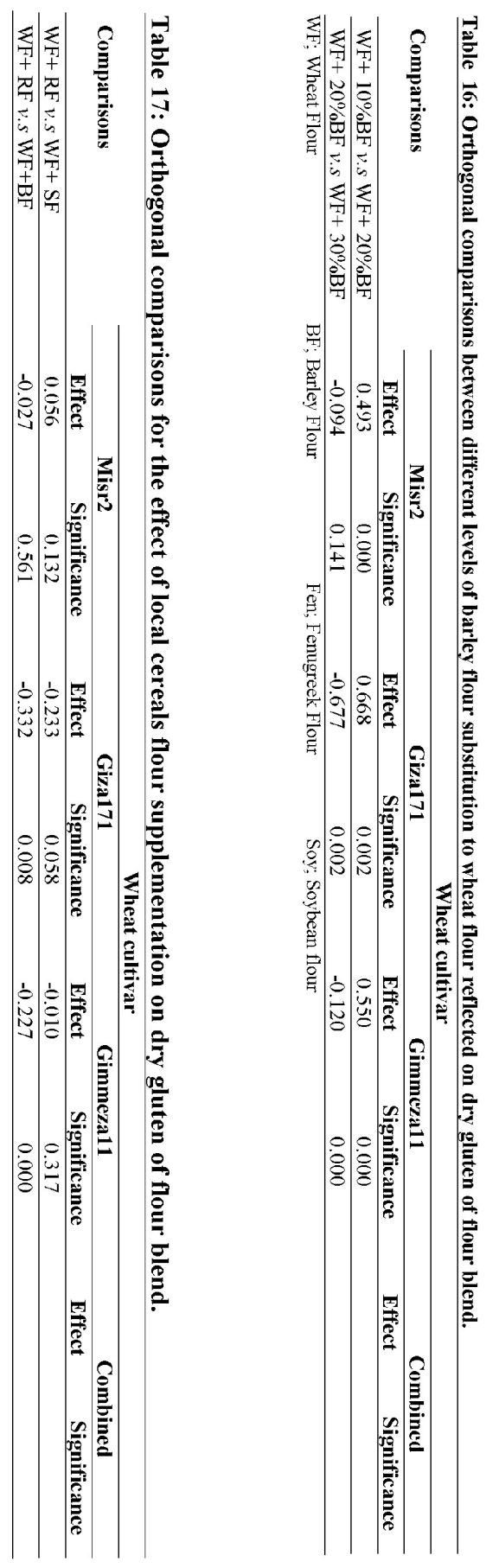




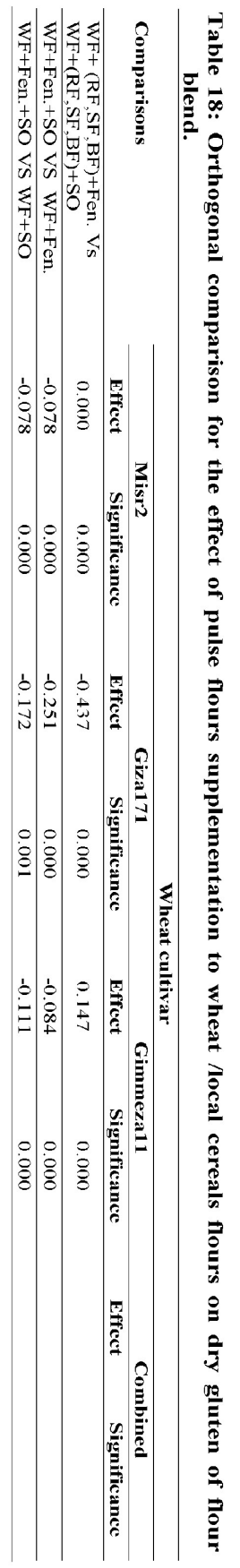


In partially substituted wheat flour with other cereals flours, the composition of flour blend's dry matter change and deviate from the composition of elemental flours composition. These modifications resulted in new values for protein, ash moisture and other related measures. They added that low levels of cereals substitution could considerably reduce the cost of raw materials and could nutritionally improve products with cereals blends. However, it is necessary to evaluate any changes in bread characteristics (Vasquez et al 2016).

Discussion regarding the role of rice flour in modifying chemical composition of flour blends included the following; Fslam et al. (2011) reached that protein content was increased by addition of rice flour. Anna-Sophie et al. (2012) showed that rice flour has low protein content. Falling number values (which are indicative of the alpha amylase activity) increased as the proportion of rice flour increased in the blend. This implied that the extent of liquefaction and diastatic activity of the starches in the blends decreased as the proportion of rice flour increased (Schiller 1984, Watson 1984 and Meera 2010).

Abdelghafor et al (2013)stated that sorghum/ wheat flour blend showed wet dry gluten percentage decreased with increasing sorghum flour in the blend. Amir et al. (2015) found that, flour blend contained $20 \%$ sorghum flour $+80 \%$ wheat flour possessed the highest percentage of protein (14.8\%) and ash $(1.79 \%)$. While, $15 \%$ maize $+15 \%$ sorghum $+70 \%$ wheat flour blend contained maximum value of moisture $(10.10 \%)$.

Sibanda et al. (2015) reached that, sorghum addition to wheat flour blends resulted in a decrease in protein and moisture content and an increase in ash content. Adeyeye (2016) revealed that, substitution of wheat flour with sorghum flour significantly increased moisture, ash and protein contents of the mixture as the percentage of sorghum substitution increased.

Niffenegger (1964) showed that the starch and protein of barley flour and that of wheat flour behave differently. The starch of barley flour has less thickening capacity and less water absorption than wheat. This might explain differences in falling number associated with replacing barley flour to wheat flour.

Dhingar and Jood (2002 and 2004) found that, the gluten content of flour blends decreased with increase in the level of soybean and barley flours separately and in combination to bread flour. Flour blends contained $20 \%$ barley flour or $20 \%$ soybean flour were of higher proximate analysis, since, increased protein, glutelin (protein fraction) and Bglucan contents of the cereal pulse blends.

Ereifej et al (2006) suggested that flour blends made from wheat and barley has higher protein and ash content Sullivan et al (2010) found that increasing barley flour percentage in barley wheat flour blends results in lower protein content. Lin et al (2012) found that, increasing levels of barley flour in wheat/ barley flour blends correspondingly decreased gluten content. Hussein et al. (2013) clewed that substituting a part of wheat flour with barley flour improved protein and ash.

Bhatt and Gupta (2015) showed the composite flours of wheat, barley and pulse had high content of protein and ash. Lalit and Kochhar (2017) showed that incorporation of barley flour at $25 \%$ level and fenugreek flour at $5 \%$ to wheat flour increased protein content.

Olaoye et al (2006) found that crude protein and ash of soy supplemented breads increased with progressive increase in the proportion of soy flour, while lowest values were recorded for the whole wheat flour. Dhingra and Jood (2004) indicated that gluten content decreased with increase in the level of soybean flour Hooda and Jood (2005) found that blends of wheat flour with fenugreek flour from 5 to $20 \%$ levels increased protein and ach contents.

Ribotta et al (2005) showed that soybean flour replacement to wheat flour gave lower gluten. Butt et al (2011) showed that increasing the level of cowpea flour substitution to wheat flour increased protein and ash content. Idrani et al.(2011) reached that inclusion of pulse flour and barley flour to wheat flour blends decreased falling number. Roberts et al (2012) showed

That fenugreek wheat flour blends had low figures of falling number relative to whole wheat flour. Srivastava et al (2012) cleared that inclusion of fenugreek to wheat flour up to $15 \%$ decreased the values of falling number Kasaye et al (2015) reached that, gluten content decreased with increasing proportion of fenugreek flour. Also, protein and ash contents increased as a result of fenugreek flour addition. Wani et al (2016) found that composite flours of pulse and wheat has lower setback viscosity (low falling) number which suggests that bread made from such blends will maintain freshness for longer period compared to wheat flour. Lalit and Kochhar (2017) indicated that blends of wheat/barley and fenugreek flour has higher protein.

\section{REFERENCES}

AACC.(1999). Approved method of American Association of cereal chemists. Published by American Association of cereal Chemists ,Inc. St., Paul,Minnesota,USA.

AACC.(2000). Approved method of American Association of cereal chemists. Published by American Association of cereal Chemists ,Inc. St., Paul,Minnesota,USA. 
Abdelghafor, R.F., A.I. Mustafa, A.M.H. Ibrahim, Y.R. Chen and P.G. Krishnan (2013). Effects of sorghum flour addition on chemical and rheological properties of hard white winter wheat. Advance Journal of Food Science and Technology, 5(11): 1407- 1412.

Abdel-Kader, Z.M. (2000). Enrichment of Egyptian 'Balady' bread. Part 1. Baking studies, physical and sensory evaluation of enrichment with decorticated cracked broad beans flour (Vicia faba L.). Nahrung 44 Nr. 6, S. 418-421.

Abou- Raya, M. A., M. M. Rabiae, A.S. El - Shazly and E.S.E- Fadaly (2014). Effect of adding barley and oat flour on the rheological propertie of bread dough. J. Food and Dairy Sci., Mansoura Univ., 5 (8):641 - 652.

Adeyeye, S.A.O. (2016). Assessment of quality and sensory properties of sorghum-wheat flour cookies. Food and Agriculture Journal, 2: 1-10.

Ahmed, A.R. (2014). Influence of Chemical Properties of Wheat-Lupine Flour Blends on Cake Quality. American Journal of Food Science and Technology, 2 (2): 67-75.

Amir, B., G. Mueen-ud-din, M. Abrar, S. Mahmood, M. Nadeem and A. Mehmood (2015). Chemical composition, rheological properties and cookies making ability of composite flours from maize, sorghum and wheat. Journal of Agroalimentary Processes and Technologies, 21(1), 28-35.

Amjid, M.R., A.Shehzad, S. Hussain, M.A. Shabbir, M.R. Khan and M. Shoaib (2013). A comprehensive review on wheat flour dough rheology. Pak. J. Food Sci., 23(2): 105-123.

Anna-Sophie, H., A. Wolter, F. Jacob, E. Zannini and E.K. Arendt (2012). Nutritional properties and ultra-structure of commercial gluten free flours from different botanical sources compared to wheat flours. Journal of Cereal Science 56: 239247.

Axford, D.W.E., K.H. Colwell, S.J. Cornford and G.A.H. Elton (1968). Effect of loaf specific volume on the rate and extent of staling in bread. J. of Science of Food and Agriculture. Article

Baker, A.E., C.E. Walker and K. Kemp (1988). An optimum compression depth for measuring bread crumb firmness. Cereal Chemistry, 65(4): 302307.

Butt, M.S., J. Iqbal, A. Naz, H.A.R. Suleria1, M.M.N. Qayyum, Faiza Saleem and M.A. Jahangir (2011). Effect of Flour Blending on Bread Characteristics. Internet Journal of Food Safety, 13: 142-149

Begum, R., M. J. Uddin, M. A. Rahman and M. S. Islam (2013). Comparative study on the development of maize flour based composite bread. J. Bangladesh, Agril. Univ. 11(1): 133139.
Bhatt, S.M. and R.K. Gupta (2015). Bread (composite flour) formulation and study of its nutritive, phytochemical and functional properties. Journal of Pharmacognosy and Phytochemistry; 4(2): 254-268.

Carson, L., C. Setser and X.S. Sun (2000). Sensory characteristics of sorghum composite bread. International Journal of Food Science and Technology, 35, 465-471.

Chandel, J. and S. Jood (2015). Sensory and nutritional characteristics of bread supplementation with linseed flour. International Journal of Food and Nutritional Science, 4(4): 234-239.

Dhingar, S. and S. Jood (2002). Physico-chemical and nutritional properties of cereal- pulse blends for bread making. Nutrition and Health, 16:183194.

Dhingra S. and S. Jood (2004). Effect of flour blending on functional, baking and organoleptic characteristics of bread. International Journal of Food Science and Technology, 39:213-222.

Eissa, H.A., A.S. Hussein and B.E. Mostafa (2007). Rheological properties and quality evaluation of Egyptian balady bread and biscuits supplemented with flours of ungerminated and germinated legume seeds or mushroom. Polish Journal of Food and Nutrition Science, 57 (4): 487-496.

Elisa Julianti, Herla Rusmarilin, Ridwansyah and Era Yusraini (2017). Functional and rheological properties of composite flour from sweet potato, maize, soybean and xanthan gum. Journal of the Saudi Society of Agricultural Sciences, 16: 171177

Ereifej, K.I., M.A. Al-Mahasneh and T.M. Rababah (2006). Effect of barley flour on quality of balady bread. International Journal of Food Properties, 9: 39-49.

Fadda, C., A.M. Sanguinetti, A.Del Caro, C. Collar and A. Piga (2014). Bread Staling: Updating the View. Comprehensive Reviews in Food Science and Food Safety, 13: 473- 492.

Filipčev, B., M. Bodroža-Solarov, M. Pestorić and O. Šimurina (2016). Breadmaking performance and textural changes during storage of composite breads made from spelt wheat and different forms of amaranth grain. Food Science and Technology International, 23(3): 235- 244.

Gray, J.A. and J.N. Bemiller (2003). Bread staling: Molecular bass and control. Comprehensive Reviews in Food Science and Food Safety, 2: 111.

Gupta HO, Singh J (1981) Developmental changes in kernel fractions and dietary fibre of normal and opaque-2 maize. J Food Sci Technol 18:142-146 
Hadnađev, T.D., A. Torbica and M. Hadnađev (2011). Rheological properties of wheat flour substitutes/alternative crops assessed by Mixolab. Procedia Food Sci., 1: 328- 334.

Harden MI, Yang SP (1975) Protein quality and supplementary value of cottonseed flour. J Food Sci 40:75-77.

Harinder, K., B. Kaur and S. Sharma (1999). Studies on the baking properties of wheat: Pigeonpea flour blends. Plant Foods for Human Nutrition, 54: 217-226.

Hooda, S. and S. Jood (2005). Effect of fenugreek flour blending on physical, organoleptic and chemical characteristics of wheat bread. Nutrition \& Food Science, 35 (4): 229-242.

Hruskova, M., I. Svec and I. Kucerova (2003). Effect of malt flour addition on the rheological properties of wheat fermented dough. Czech J. Food Sci., 21(6): 210-218.

Hussein, A.M.S., M.M. Kamil, Nefisa A. Hegazy and S.A.H. Abo El-Nor (2013). Effect of wheat flour supplemented with Barley and/ or corn flour on balady bread quality. Pol. J. Food Nutr. Sci., 63(1): 11-18.

Hussein, A.M.S., M.M. Kamil, Nefisa A. Hegazy, S.A.H. Abo El-Nor (2013). Effect of Wheat Flour Supplemented with Barely and/or Corn Flour on Balady Bread Quality. Pol. J. Food Nutr. Sci., 63(1): 11-18.

Indrani, D., P.Swetha, C.Soumya, J. Rajiv and G.V. Rao (2011). Effect of multigrains on rheological, microstructural and quality characteristics of north Indian parotta - An Indian flat bread. Food Science and Technology, 44 (3):719-724.

Islam, M.Z., M. Shams-Ud-Din and M.A. Haque (2011). Studies on the effect of brown rice and maize flour on the quality of bread. Bangladesh Agril. Univ. 9(2): 297-304.

Ivan, Š., Marie Hrušková, J. Karas and T. Hofmanová (2012). Solvent Retention Capacity for Different Wheats and Flours Evaluation. Czech Journal of Food Science. 30 (5): 429-437.

Kameni, A, C.Kouebou, D.A.K. Aboubakar and C. The (2014). Effect of wheat flour substitution, maize variety and fermentation time on the characteristics of Akara, a deep oil fried dough product. Academic Journals, 8(3): 104-111.

Kasaye, A.T. and Y.K. Jha (2015). Evaluation of composite blends of fermented fenugreek and wheat flour to assess its suitability for bread and biscuit. International Journal of Nutrition and Food Science. 4(1): 29-35.

Khoshgozaran-Abras, S., M. H. Azizi, N. Bagheripoor-Fallah and A. Khodamoradi (2014). Effect of brown rice flour fortification on the quality of wheat-based dough and flat bread. J. Food Sci. Technol., 51(10): 2821-2826.
Lalit, H. and A. Kochhar (2017). Development and organoleptic evaluation of bread formulated by using wheat flour, barley flour and germinated. Chem. Sci. Rev. Lett., 6(23): 1728-1734.

Lilia Belghith Fendri, Fatma Chaari, Marwa Maaloul, Fatma Kallel, Lobna Abdelkafi, Semia Ellouz Chaabouni and Dhouha Ghribi-Aydi (2016). Wheat bread enrichment by pea and broad bean pods fibers: Effect on dough rheology and bread quality. LWT - Food Science and Technology, 73: 584-591.

Lin, S.Y., H.H. Chen, S. Lu and P.C. Wang (2012). Effects of blendings of wheat flour with barely flour on dough and steamed bread properties. Journal of Texture Studies 43: 438- 444.

López, A.C.B., A.J.G. Pereira and R.G. Junqueira (2004). Flour mixture of rice flour, corn and cassava starch in the production of gluten-free white bread. Brazilian Arcgives of Biology and Technology, 47(1): 63-70.

Maiya, G.K., B.G. Shwetha and D. Indrani. (2013). Effect of barley flour on rheological characteristics of dough, organoleptic, nutritional and storage characteristics of south Indian parotta. Food Science and Technology International, 21(1): 24-32.

Maria, Dolores Alvarez, B. Herranz, R. Fuentes. F.J. Cuesta and W. Canet (2017). Replacement of wheat flour by chickpea flour in muffin batter: Effect on rheological properties. Journal of Food Process Engineering, 40: 1-13.

Marie Hrušková and I. Švec (2015). Chemical, rheological and bread characteristics of wheat flour influenced by different forms of chia (Salvia hispanica L.). Emirates Journal of Food and Agriculture. 27(12): 872-877.

Mariotti, M., C. Garofalo, L. Aquilanti, A. Osimani, L. Fongaro, S.Tavoletti, Anna-Sophie Hager and F.Clementi (2014). Barley flour exploitation in sourdough bread-making: A technological, nutritional and sensory evaluation. LWT - Food Science and Technology, 59(2): 973-980.

Meer,k.(2010). Falling number in wheat -how is it calculated and what does it mean to producers? USA: USDA,ARS, soft wheat quality lab. Alpha amylase mkweon -FN-012810 pdf.(Accessed 19 may 2011).

Menon, L. and S.D. Majumdar (2015). Development and analysis of composite flour bread. J. Food Sci. Technol., 52(7): 4156-4165.

Miñarro, B., E. Albanell, N. Aguilar, B. Guamis and M. Capellas (2012). Effect of legume flours on baking characteristics of gluten-free bread. Journal of Cereal Science 56: 476- 481.

Mohammed, I., A.R. Ahmed, B. Senge (2012). Dough rheology and bread quality of wheatchickpea flour blends. Industrial Crops and Products 36:196-202.

M.S.Barlett(1937)properties of sufficiency and statistical tests.160: 901 
MSTAT-C(1086). Amicrocomputer program for the Design and analysis of agronomic research experiment Michigan state univ., USA

Nareman S. Eshak (2016). Sensory evaluation and nutritional value of balady flat bread supplemented with banana peels as a natural source of dietary fiber. Annals of Agricultural Science (2016) 61(2), 229-235

Navickis, L. L. (1987). Corn Flour Addition to Wheat Flour DoughsEffect on Rheological Properties. Cereal Chemists, 64(5): 307- 310.

Niffenegger, E.V. (1964), chemical and physical characteristics of barley flour as related to its use in baked products. A thesis submitted to the Graduate Faculty in partial fulfillment of the requirements for the degree of Master of Science in Home Economics, Montana State College Bozeman, Montana.

Nigam, V. and V.S. Nambiar (2015). Recent trends in modification of wheat bread as functional bread- A review. International Journal of Innovative Research and Studies. 4(4): 128-148.

Noorfarahzilah, M., J. S. Lee, M. S. Sharifudin, A. B. Mohd Fadzelly and M. Hasmadi (2015). Applications of composite flour in development of food products. International Food Research Journal 21(6): 2061-2074.

Nwanekezi, E.C. (2013). Composite Flours for Baked Products and Possible Challenges - A Review. Official Journal of Nigerian Institute of Food Science and Techonology, 31(2): 8-17.

Nwosu, U.L., C.U. Elochukwu and C.O. Onwurah (2014). Physical characteristics and sensory quality of bread produced from wheat/ African oil bean flour blends. African Journal of Food Science, 8(6): 351-355.

Okaka JC, Potter NN (1977) Functional and strorage properties of cowpea powder-wheat flour blends in bread making. J Food Sci 42:828-833

Olaoye, O.A., A.A. Onilude and O.A. Idowu (2006). Quality characteristics of bread produced from composite flours of wheat, plantain and soybeans. African Journal of Biotechnology, 5(11): 1102-1106.

Oloyede, O.O., O.B. Ocheme and L.M. Nurudeen (2013). Physical, Sensory and Microbiological Properties of Wheat-Fermented Unripe Plantain Flour. Official Journal of Nigerian Institute of Food Science and Techonology, 31(2): 123-129.

Phimolsiripol, Y., A. Mukprasirt and R. Schoenlechner (2012). Quality improvement of rice-based gluten-free bread using different dietary fibre fractions of rice bran. Journal of Cereal Science 56: 389-395.

Popa, C.N., Radiana-Maria Tamba-Berehoiu, AnaMaria Hutan and S. Popescu (2014). The significance of some flour quality parameters as quality predictors of bread. Scientific Bulletin. Series F. Biotechnologies, XVIII: 135-140.
Qarooni, J., R.A. Orth and M. Wootton (1987). A test baking technique for Arabic bread quality. Cereal Science Journal, 6: 69-80.

Rai, S., A. Kaur, B. Singh and K.S. Minhas (2012). Quality characteristics of bread produced from wheat, rice and maize flours. Food Sci Technology, 49(6): 786-789.

Reddy, M.M., R. P. Reddy, R. Prasad and U. Munilakshmi (2013). Grain and Milling Quality of Barley and Their Suitability for Preparation of Traditional South Indian Products. IOSR Journal of Pharmacy, 4 (2): 23-27.

Ribotta, P.D, S.A. Arnulphi, A.E. León and M.C. Añon (2005). Effect of soybean addition on the rheological properties and breadmaking quality of wheat flour. J Sci Food Agric 85:1889-1896.

Roberts, K.T., S.W. Cui, Y.H. Chang, P.K.W. Ng and T. Graham (2012). The influence of fenugreek gum and extrusion modified fenugreek gum on bread. Food Hydrocolloids 26: $350-358$.

Różyło, R. and J. Laskowski (2011). Predicting Bread Quality (Bread Loaf Volume and Crumb Texture). Pol. J. Food Nutr. Sci., 61 (1):61-67.

Samuel A. Matz(1972). Bakery technology and engineering. AVI publishing co., Westport,Connecticut 590-595

Sawsan Y. El-Faham, E.A. Abd El-Hamid and H.K. Ashour (2010). Barley flour and durum blends in Macaroni product. Australian Journal of Basic and Applied Sciences, 4(12): 6169-6178.

Schiller,G.w.(1984). Bakery flour specification.CFW 29: $647-651$.

Sharma, S. and U.Bajwa and H.P.S. Nagi (1999). Rheological and baking properties of cowpea and wheat flour blends. J. Sci. Food Agric., 79: 657-662.

Sidhu, J.S., J.Al-Saqer and S. Al-Zenki (1997). Comparison of methods for the assessment of the extent of staling in bread. Food Chemistry, 58(1-2): 161-167.

Sollars, W.F. and G.L. Rubenthaler (1971). Performance of wheat and other starches in reconstituted flours. Wheat and Starches in Flours, 48: 397- 410.

Sibanda, T., T. Ncube and N. Ngoromani (2015). Rheological Properties and Bread Making Quality of White Grain Sorghum-Wheat Flour Composites. International Journal of Food Science and Nutrition Engineering, 5(4): 176182.

Srivastava, D., J. Rajiv, Mahadevamma, M.M. Naidu (2012). Effect of Fenugreek Seed Husk on the Rheology and Quality Characteristics of Muffins. Food and Nutrition Sciences, 2012, 3, 1473-1479 
Sullivan, P., J. O'Flaherty, N. Brunton, E. Arendt and E. Gallagher (2010). Fundamental rheological and textural properties of doughs and breads produced from milled pearled barley flour. Eur Food Res. Technol., 231: 441-453.

Tanaka, Y. (1972). Quality Improvement of Rice Bread. Jarq J., 6(3): 181-187.

Tulse, S.B., V. Reshma, J. Rajiv and S.D. Sakhare (2014). Effect of co-milled wheat, green gram and barley on the rheological and quality characteristics of cookies. Food Science and Technology International, 21(7): 492-502.

Vásquez, F., S. Verdú, Alma R. Islas., José M. Barat and R. Grau (2016). Effect of low degrees of substitution in wheat flour with sorghum, oat or corn flours on physicochemical properties of composite flours. Food Science and Technology, 2: $1-12$
Wani, I.A., D.S. Sogi, P. Sharma and B. Singh (2016). Physicochemical and pasting properties of unleavened wheat flat bread (Chapatti) as affected by addition of pulse flour. Cogent Food and Agriculture, 2:19.

Watson,C.A.(1984). An instrument for determining alpha-amylase activity . CFW 29:507-509.

Yaseen, A.A., A. Sh. Abd-El-Hafeez and M.S. Mostafa (2007). Egyptian balady bread and biscuit quality of wheat and Triticale flour blends. Pol. J. Food Nutr. Sci., 57 (1): 25-30.

Year Book of Agriculture satistics , (2016). Ministry of agriculture and land reclamation, Egypt.

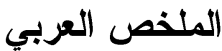

\section{احلال دقيق الحبوب والبقول المحليه محل دقيق القـح كاسلوب لمعالجة نقص القـح فى مصر محتوى الدقيث من البروتين والجلوتين الجاف}

\author{
زينب راقت عطيه، مسعد محمد عبد السيد الجنبيهى ومحمد عبد الستار احمد \\ قسم علوم المحاصبل كلية الزر اعه جامعة الاسكندريه
}

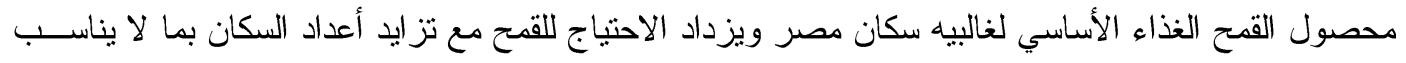

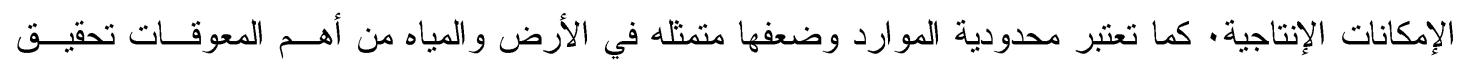

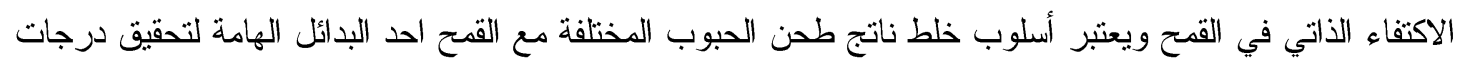

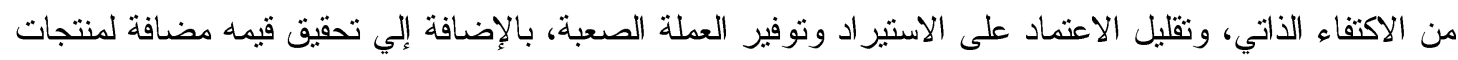

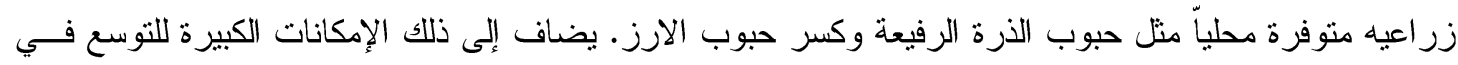

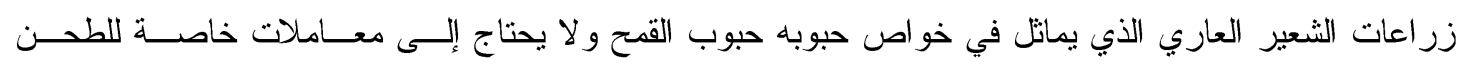

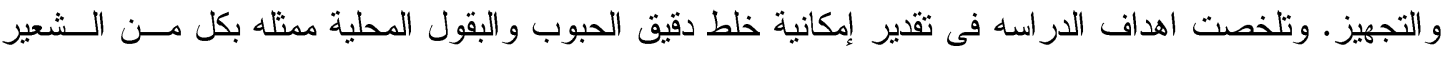

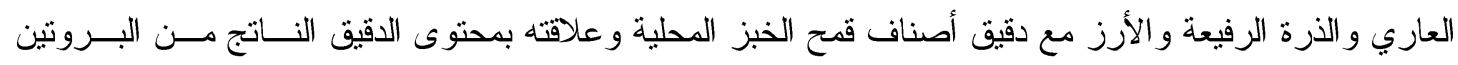
و الجلوتين الجاف ويمكن تلخيص اهم النتائج المتحصل عليها فى التالى: - خلطات الدقيق المحتويه على احلا دقيق الارز فى مقليل الخلطات المحتويه على احلا دقيق الـذـره الرفيعـه

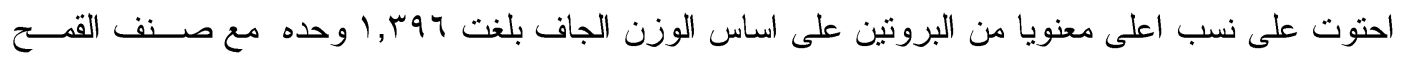

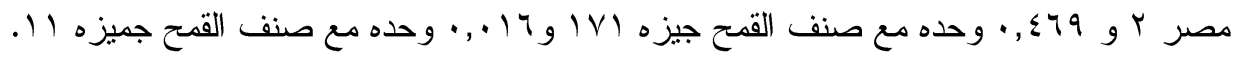

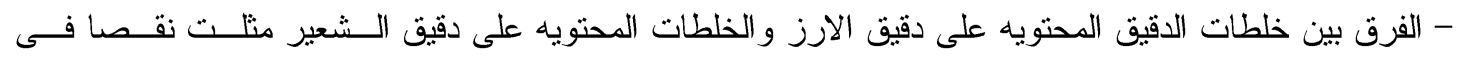

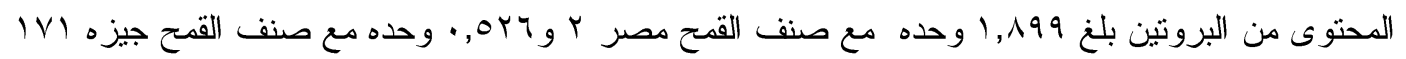

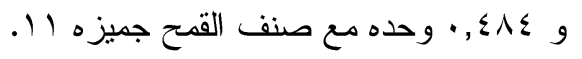


- تاثير احلال دقيق الحلبه فى الخلطات على المحتوى من البروتين اظهر ان خلطات دقيق الحلبه مع دقيق الحبوب

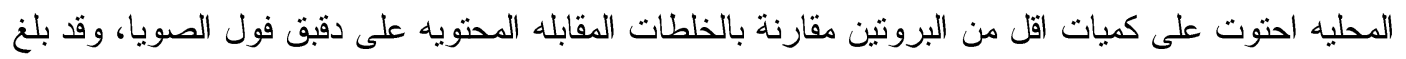

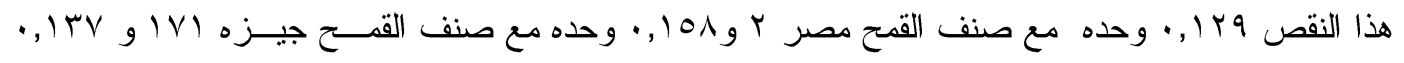

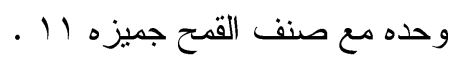

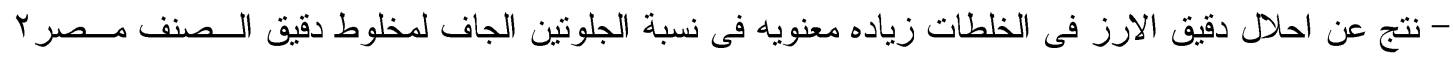

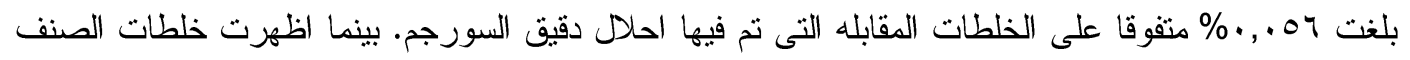

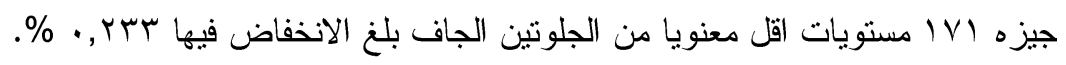

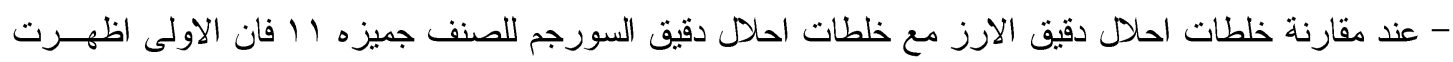

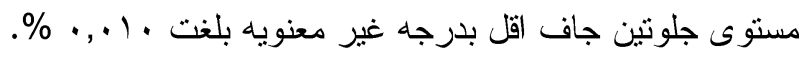

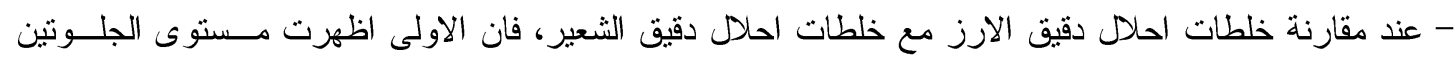

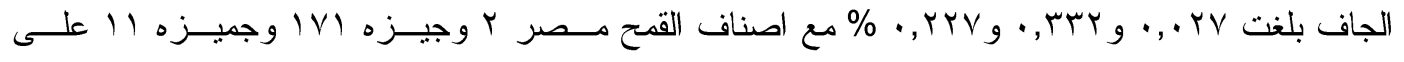
الترتيب.

- الخلطات التى شملت احل دقبق الحلبه بنسبة ه \% و دقيق فول الصويا بنسبة ه \%، احتوت على مستويات اقل

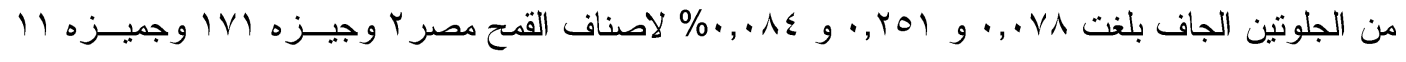

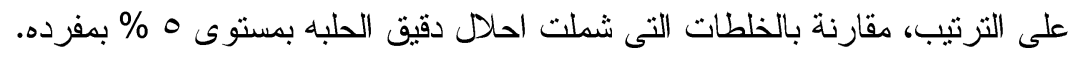

